\title{
中国灌丛生态系统碳储量的研究
}

谢宗强 $^{1^{*}}$ 唐志尧 ${ }^{2}$

${ }^{1}$ 中国科学院植物研究所植被与环境变化国家重点实验室, 北京 100093 ; ${ }^{2}$ 北京大学城市与环境学院, 北京 100871

引用格式：谢宗强, 唐志尧 (2017). 中国灌丛生态系统碳储量的研究. 植物生态学报, 41, 1-4. doi: 10.17521/cjpe.2017.0012

\section{Studies on carbon storage of shrubland ecosystems in China}

XIE Zong-Qiang $^{*}$ and TANG Zhi-Yao ${ }^{2}$

${ }^{1}$ State Key Laboratory of Vegetation and Environmental Change, Institute of Botany, Chinese Academy of Sciences, Beijing 100093, China; and ${ }^{2}$ College of Urban and Environmental Sciences, Peking University, Beijing 100871, China

Citation: Xie ZQ, Tang ZY (2017). Studies on carbon storage of shrubland ecosystems in China. Chinese Journal of Plant Ecology, 41, 1-4. doi: 10.17521/cjpe.2017.0012

灌丛的生态适应范围极为广泛, 是中国山地和 干旱地区极为常见的植被类型。近年来, 由于退化 植被的恢复及重建, 中国灌从植被的分布面积增长 迅速, 成为独具特色的植被类型。虽然灌从植被分 布广泛并且类型复杂多样, 但它在中国植被水平分 布带中不占有显著地位; 在青藏高原和云贵高原的 山地垂直带上常有原生灌从分布, 在全国各地有许 多次生性灌从类型, 并有明显的地区性和生物生态 学差异。依据其群落特征和生态地理特点, 中国灌 从可分为常绿针叶灌从、常绿革叶灌从、落叶阔叶 灌从、常绿阔叶灌丛和灌草丛 5 类(中国植被编辑委 员会, 1980)。

由于对灌丛植被的定位以及不同行业部门认识 的偏差, 中国一直未专门针对灌从开展系统性的调 查工作, 同时灌丛生物量测定较为困难, 灌丛植被 分布变化迅速, 因此灌从调查数据匮乏, 有关其生 物量及动态等的研究极为薄弱。然而作为一种重要 的陆地生态系统类型, 灌从在群落演替和生物固碳 等方面扮演着不可替代的角色(Piao et al., 2009)。目 前有关中国灌从碳汇主要还是通过植被生产力和碳 汇之间的关系、植被平均碳密度法粗略估计(胡会峰 等, 2006; 方精云等, 2007)。相对于森林和草地生态 系统而言, 对灌丛生态系统固碳速率、潜力及机制 的认识非常有限。

为了准确地评估中国灌丛生态系统的碳储量现
状和变化，中国科学院战略性先导科技专项“应对 气候变化碳收支认证及相关问题”设立了 “中国灌从 生态系统的固碳现状、变化和机制”课题。课题根据 中国灌从植被的类型和分布, 选择具有代表性的样 地, 采取统一的标准和方法(生态系统固碳项目技 术规范编写组, 2015)对典型灌从生态系统碳储量、 空间分布和碳汇形成机制进行系统调查、实验研究 以及模型模拟。课题的一个重要特点是通过大量的 野外调查, 从生态系统尺度(样地尺度)精确计量碳 循环主要过程(包括碳循环各组分储量和变化量), 以利于区域尺度碳循环的评估和模型校验, 并对现 有灌从碳循环研究进行精度检验和不确定性分析。 为此, 课题采用统一的技术规范, 对中国灌从生态 系统类型碳循环各组分进行精细计量, 建立一套完 整的、标准化的灌从碳循环参数体系, 构建国家尺 度灌丛碳源汇估算校验基准点网络, 为建立和改良 适合中国特点的碳模型提供基本参数; 根据灌从的 特点, 通过养分控制实验等手段, 阐明灌从生态系 统的碳源汇形成和调控机制, 探明增强碳汇潜力的 可能途径。

课题的总体技术路线如图1所示。具体技术方案 包括 4 个方面:

(1)实地测定：参考 1:100万中国植被图(中国科 学院中国植被图编辑委员会, 2007)的灌丛分布, 按 面积权重分层随机取样布设采样区, 选择1000-

收稿日期Received: 2017-01-04 接受日期Accepted: 2017-01-04

*E-mail: xie@ibcas.ac.cn 


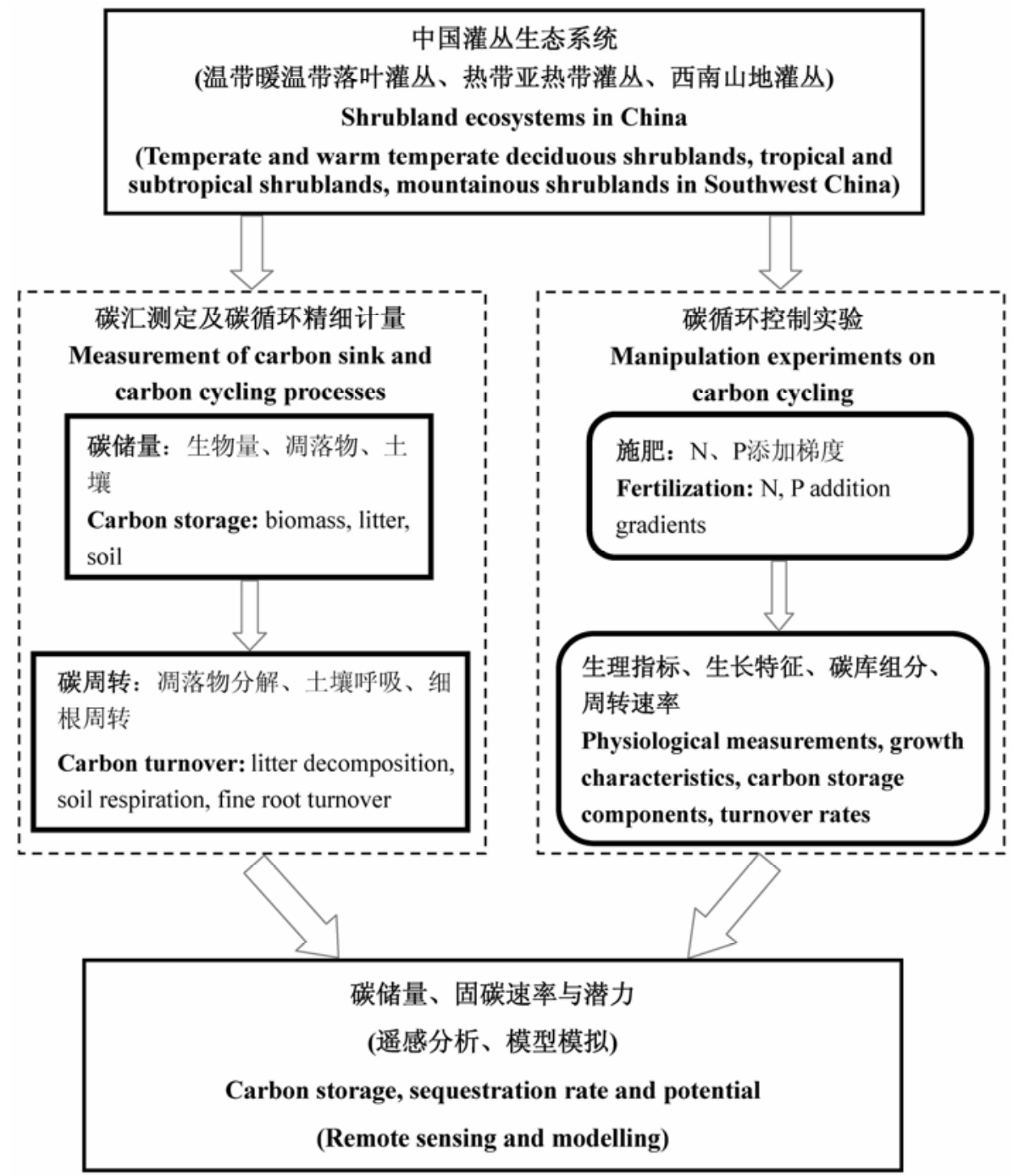

图1 中国灌丛生态系统的碳储量、固碳速率和机制研究的技术途径。

Fig. 1 Approaches to evaluate the rates and mechanisms of carbon sequestration of shrubland ecosystems in China.

1200 个代表性灌丛样地，测定植被各组分(叶、枝、 干、粗根、细根)的碳库及其变化量、土壤碳密度及 其变化量。

(2)遥感分析：收集不同分辨率的遥感影像, 建 立实测结果与遥感信息之间的统计关系, 分析区域 尺度上碳储量的变化及速率。

(3)控制实验: 选择20个代表性灌从样地进行施 肥(氮和磷)和灌溉控制实验, 研究养分供应与水分 变化对碳源汇过程的影响。

(4)模型模拟: 利用生态系统模型模拟不同温室 气体排放情景下, 灌从生态系统碳源汇强度的时空 变化格局和增汇潜力。生态系统模型模拟研究中所 需要的输入数据包括: 气候、土壤、土地利用方式 和人为管理。采用地理信息系统(GIS)技术对点状数
据(历史气候数据、土壤剖面数据)和面状数据(土地 利用方式和人为管理)进行空间化处理及一致性处 理(包括计量单位的统一、数据分类系统及编码等的 标准化)。通过对这些数据内容的一致性处理和格式 转换, 最终形成用于模型运算的空间参数数据库。

该课题成员包括中国科学院植物研究所、北京 大学、中国科学院成都生物研究所、中国科学院华 南植物园、中国科学院武汉植物园、中国科学院青 藏高原研究所、中国科学院新疆生态与地理研究所、 内蒙古大学等 10 多家单位近 100 名科研人员。经过 5 年艰辛奋斗, 共调查代表性灌从样地 1258 个, 采集 植物样品23809份、土壤样品34 141份, 形成首个中 国灌从生态系统碳储量数据库。基于这些数据，估 算中国灌丛生态系统碳储量总量为6 713.3 Tg C。 
本专辑主要介绍该课题的有关研究成果。专辑 共收录15篇研究论文, 内容包含了灌从生态系统碳 循环研究的各个方面。李家湘等(2017a)研究了亚热 带灌从植物生活型组成及其与水热因子的关系。罗 永开等(2017)、王杨等(2017)分别建立了不同地区常 见灌木生物量方程, 并研究其生物量分配特征。在 不同区域, 研究团队分别利用生物量方程估算了相 应区域典型灌从生态系统的土壤碳密度与生物量碳 密度及其在不同组分之间的分配(崔光帅等, 2017; 杨路存等, 2017; 张菩等, 2017b); 基于常见类型灌 丛生态系统的生物量碳密度和土壤碳密度, 杨弦等 (2017)、郭炎培等(2017)分别估算了我国北方灌从生 物量以及生态系统碳、氮、磷储量, 葛结林等(2017) 估算了我国南方灌从调落物现存量。为了研究灌从 生态系统对氮沉降的响应, 张菩等(2017a)和张建华 等(2017a，2017b)分别对我国南北方典型灌从进行 氮添加实验。在探讨灌从生态系统碳循环的养分限 制方面, 重点研究了青藏高原东部窄叶鲜卑花(贺合 亮等, 2017)、云南杨梅(苏凯文等, 2017)以及中国南 方灌从优势灌木的碳、氮、磷化学计量特征(李家湘 等, 2017b)。

本专辑没有涵盖中国所有灌从生态系统, 但从 典型灌丛类型到区域尺度上灌从生态系统物种组 成、碳储量、化学计量特征以及灌从生态系统对氮 沉降的响应等研究, 均有助于了解灌从生态系统在 不同的空间和类型上的固碳特征。

基金项目中国科学院战略性先导科技专项 (XDA5050300)。

致谢 感谢“生态系统固碳现状、速率、机制和潜力” 项目首席科学家方精云和于贵瑞对本课题的设计和 运行给予的指导, 项目办公室及各课题负责人在 “灌丛课题”实施过程中给予的支持, 课题秘书徐文 婷及课题骨千刘庆、熊高明、李跃林、于顺利、尹 春英、尹华军、周国英、赵春章、张林、赵常明、 卢志军、刘鸿赝、马文红、安尼瓦尔·买买提、吉成 均、赵霞等的辛勤付出, 中国科学院植物研究所碳 项目办公室陈雅涵、刘运通、杨志强加班加点测试 样品。

\section{参考文献}

Cui GS, Zhang L, Shen W, Liu XS, Wang YT (2017). Biomass allocation and carbon density of Sophora moorcroftiana shrublands in the middle reaches of Yarlung Zangbo River, Xizang, China. Chinese Journal of Plant Ecology,
41, 53-61. (in Chinese with English abstract) [崔光帅, 张 林, 沈维, 刘新圣, 王媛搯 (2017). 西藏雅鲁藏布江流 域中段砂生槐灌从生物量分配及碳密度. 植物生态学 报, 41, 53-61.]

Fang JY, Guo ZD, Piao SL, Chen AP (2007). Terrestrial vegetation carbon sinks in China, 1981-2000. Science China: Earth Sciences, 37, 804-812. (in Chinese) [方精 云, 郭兆迪, 朴世龙, 陈安平 (2007). 1981 2000年中国 陆地植被碳汇的估算. 中国科学: 地球科学, 37, 804-812.]

Ge JL, Xiong GM, Li JX, Xu WT, Zhao CM, Lu ZJ, Li YL, Xie ZQ (2017). Litter standing crop of shrubland ecosystems in southern China. Chinese Journal of Plant Ecology, 41, 5-13. (in Chinese with English abstract) [葛 结林, 熊高明, 李家湘, 徐文婷, 赵常明, 卢志军, 李跃 林, 谢宗强 (2017). 中国南方灌丛调落物现存量. 植物 生态学报, 41, 5-13.]

Guo YP, Yang X, Mohhamot A, Liu HY, Ma WH, Yu SL, Tang ZY (2017). Storage of carbon, nitrogen and phosphorus in temperate shrubland ecosystems across Northern China. Chinese Journal of Plant Ecology, 41, 14-21. (in Chinese with English abstract) [郭炎培, 杨弦, 安尼瓦 尔·买买提, 刘鸿雁, 马文红, 于顺利, 唐志尧 (2017). 中国北方温带灌丛生态系统碳、氮、磷储量. 植物生态 学报, 41, 14-21.]

He HL, Yang XC, Li DD, Yin CY, Li YX, Zhou GY, Zhang L, Liu Q (2017). Stoichiometric characteristics of carbon, nitrogen and phosphorus of Sibiraea angustata shrub on the eastern Qinghai-Xizang Plateau. Chinese Journal of Plant Ecology, 41, 126-135. (in Chinese with English abstract) [贺合亮, 阳小成, 李丹丹, 尹春英, 黎云祥, 周国英, 张林, 刘庆 (2017). 青藏高原东部窄叶鲜卑花 碳、氮、磷化学计量特征. 植物生态学报, 41, 126-135.] Hu HF, Wang ZH, Liu GH, Fu BJ (2006). Vegetation carbon storage of major shrublands in China. Chinese Journal of Plant Ecology (Chinese Version), 30, 539-544. (in Chinese with English abstract) [胡会峰, 王志恒, 刘国华, 傅伯杰 (2006). 中国主要灌从植被碳储量. 植物生态学 报, 30, 539-544.]

Li JX, Xiong GM, Xu WT, Li YL, Lu ZJ, Zhao CM, Xie ZQ (2017). Composition of plant life forms of subtropical shrubland in China and its correlation with temperature and precipitation. Chinese Journal of Plant Ecology, 41, 147-156. (in Chinese with English abstract) [李家湘, 熊 高明, 徐文婷, 李跃林, 卢志军, 赵常明, 谢宗强 (2017). 中国亚热带灌从植物生活型组成及其与水热因 子的相关性. 植物生态学报, 41, 147-156.]

Li JX, Xu WT, Xiong GM, Wang Y, Zhao CM, Lu ZJ, Li YL, Xie ZQ (2017). Leaf nitrogen and phosphorus concentration and the empirical regulations in dominant woody plants of 
shrublands across southern China. Chinese Journal of Plant Ecology, 41, 31-42. (in Chinese with English abstract) [李家湘, 徐文婷, 熊高明, 王杨, 赵常明, 卢 志军, 李跃林, 谢宗强 (2017). 中国南方灌丛优势木本 植物叶的氮、磷含量及其影响因素. 植物生态学报, 41, 31-42.]

Luo YK, Fang JY, Hu HF (2017). Biomass estimation models and allocation patterns of 14 shrub species in Mountain Luya, Shanxi, China. Chinese Journal of Plant Ecology, 41, 115-125. (in Chinese with English abstract) [罗永开, 方精云, 胡会峰 (2017). 山西芦芽山14种常见灌木生物 量模型及生物量分配. 植物生态学报, 41, 115-125.]

Piao SL, Fang JY, Ciais P, Peylin P, Huang Y, Sitch S, Wang T (2009). The carbon balance of terrestrial ecosystems in China. Nature, 458, 1009-1013.

Su KW, Chen LH, Zheng W, Pan Y, Yin HJ, Gong HD (2017). Carbon, nitrogen and phosphorus stoichiometry of Myrica nana in Yunnan Province. Chinese Journal of Plant Ecology, 41, 136-146. (in Chinese with English abstract) [苏凯文, 陈路红, 郑伟, 潘瑶, 尹华军, 巩合德 (2017). 云南杨梅碳、氮、磷化学计量特征. 植物生态学报, 41 , 136-146.]

Technical Manual Writing Group of Ecosystem Carbon Sequestration Project (2015). Observation and Investigation for Carbon Sequestration in Terrestrial Ecosystems. Science Press, Beijing. (in Chinese) [生态系统固碳项目技术规范 编写组 (2015). 生态系统固碳观测与调查技术规范. 科 学出版社, 北京.]

The Editorial Committee of Vegetation Map of China, Chinese Academy of Sciences (2007). Vegetation Map of the People's Republic of China 1:1000000. Geological Publishing House, Beijing. (in Chinese) [中国科学院中国 植被图编辑委员会(2007). 中华人民共和国植被图 1:1 000 000. 地质出版社, 北京.]

The Editorial Committee of Vegetation of China (1980). Vegetation of China. Science Press, Beijing. (in Chinese) [中国植被编辑委员会 (1980). 中国植被. 科学出版社, 北京.]

Wang Y, Xu WT, Xiong GM, Li JX, Zhao CM, Lu ZJ, Li YL, Xie ZQ (2017). Biomass allocation patterns of Loropetalum chinense. Chinese Journal of Plant Ecology, 41, 105-114. (in Chinese with English abstract) [王杨, 徐 文婷, 熊高明, 李家湘, 赵常明, 卢志军, 李跃林, 谢宗 强 (2017). 䊾木生物量分配特征. 植物生态学报, 41, 105-114.]
Yang LC, Li CB, Ning Y, Nie XQ, Xu WH, Zhou GY (2017). Carbon density and its spatial distribution in the Potentilla fruticosa dominated alpine shrub in Qinghai, China. Chinese Journal of Plant Ecology, 41, 62-70. (in Chinese with English abstract) [杨路存, 李长斌, 宁神, 聂秀青, 徐文华, 周国英 (2017). 青海高寒金露梅灌从碳密度及 其分配格局. 植物生态学报, 41, 62-70.]

Yang X, Guo YP, Mohhamot A, Liu HY, Ma WH, Yu SL, Tang ZY (2017). Distribution of biomass in relation to environments in shrublands of temperate China. Chinese Journal of Plant Ecology, 41, 22-30. (in Chinese with English abstract) [杨弦, 郭炎培, 安尼瓦尔·买买提, 刘 鸿雁, 马文红, 于顺利, 唐志尧 (2017). 中国北方温带 灌丛生物量的分布及其与环境的关系. 植物生态学报, 41, 22-30.]

Zhang JH, Tang ZY, Shen HH, Fang JY (2017a). Responses of growth and litterfall production to nitrogen addition treatments from common shrublands in Mt. Dongling, Beijing, China. Chinese Journal of Plant Ecology, 41, 71-80. (in Chinese with English abstract) [张建华, 唐志尧, 沈海花, 方精云 (2017a). 北京东灵山地区常见灌从生长及调落 物生产对氮添加的响应. 植物生态学报, 41, 71-80.]

Zhang JH, Tang ZY, Shen HH, Fang JY (2017b). Effects of nitrogen addition on soil respiration in shrublands in Mt. Dongling, Beijing, China. Chinese Journal of Plant Ecology, 41, 81-94. (in Chinese with English abstract) [张建华, 唐 志尧, 沈海花, 方精云 (2017b). 氮添加对北京东灵山 地区灌从土壤呼吸的影响. 植物生态学报, 41, 81-94.]

Zhang Q, Li JX, Xie ZQ (2017a). Effects of nitrogen addition on soil respiration of Rhododendron simsii shrubland in the subtropical mountainous areas of China. Chinese Journal of Plant Ecology, 41, 95-104. (in Chinese with English abstract) [张蓄, 李家湘, 谢宗强 (2017a). 氮添 加对亚热带山地杜鹃灌从土壤呼吸的影响. 植物生态 学报, 41, 95-104.]

Zhang Q, Li JX, Xu WT, Xiong GM, Xie ZQ (2017b). Estimation of biomass allocation and carbon density of Rhododendron simsii shrubland in the subtropical mountainous areas of China. Chinese Journal of Plant Ecology, 41, 43-52. (in Chinese with English abstract) [张蓄, 李家湘, 徐文婷, 熊高明, 谢宗强 (2017b). 中国亚热带山地杜 鹃灌从生物量分配及其碳密度估算. 植物生态学报, 41, 43-52.]

责任编辑：谢 巍 


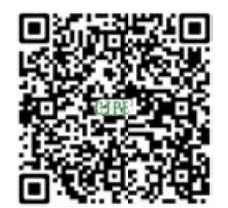

植物生态学报官网

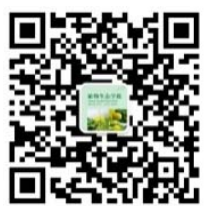

微信订阅号

期刊及学科

相关信息发布

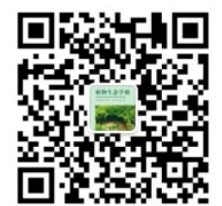

微信服务号

稿件状态查询

全文检索浏览 